\title{
子宮体癌に対する腹腔鏡下手術のfeasibilityに関する後方視的検討
}

\author{
新百合ヶ丘総合病院 \\ 竹本周二、別宮若菜、佐々木恵子、佐藤美和、益子尚子、中村浩敬、 \\ 向田幸子、奥野さつき、原 周一郎、浅井 哲、塚田ひとみ、 \\ 永井 崇、田島博人、浅田弘法、鈴木光明、吉村泰典
}

\section{A retrospective study on feasibility and safety of laparoscopic surgery for endometrial cancer}

\author{
Shuji Takemoto, Wakana Beck, Keiko Sasaki, Miwa Sato, Takako Mashiko, Hirotaka Nakamura, \\ Yukiko Mukouda, Satsuki Okuno, Shuichiro Hara, Satoshi Asai, Hitomi Tsukada, Takashi Nagai, \\ Hiroto Tajima, Hironori Asada, Mitsuaki Suzuki, Yasunori Yoshimura \\ Department of Obstetrics and Gynecology, Shin-Yurigaoka General Hospital
}

\begin{abstract}
Objective: To clarify the feasibility and safety of laparoscopic surgery for endometrial cancer.

Materials and Methods: Ninety-one patients with endometrial cancer who had undergone laparoscopic surgery in our institution between August 2012 and June 2016 were retrospectively studied. Data regarding surgical procedures, blood loss, surgical time, number of harvested lymph nodes, complications, and prognosis of the patients were obtained from medical records and analyzed.

Results: All patients had a pathologically confirmed endometrial cancer before the surgery, and their median age was 56 years. Of these, 57 patients underwent total laparoscopic hysterectomy (TLH) and bilateral salpingo-oophorectomy (BSO), and 34 patients underwent lymph node dissection in addition to TLH and BSO. After the surgery, histological examination showed that $78 \%$ of cases were high-grade endometrioid adenocarcinoma and $69.2 \%$ were the International Federation of Gynecology and Obstetrics (FIGO) stage IA. No case needed conversion to laparotomy or blood transfusion. Based on the Common Terminology Criteria for Adverse Events, complications with grade 3 or more were seen in $6.6 \%$ of patients intra-operatively, including venous and nerve injury, and seen in $6.6 \%$ of patients postoperatively, including ileus and pelvic abscess. During the follow up period (median of 23 months), 5 patients experienced recurrence, and no patient died of cancer. The rate of complications, number of harvested lymph nodes, and rate of good prognosis of our patients were not lower than that reported by previous studies.

Conclusion: The safety of laparoscopic surgery for endometrial cancer performed in our institution was found to similar to that performed in other countries. It should be more widely used worldwide and in Japan for stage IA patients and might be considered for patients with stage IB or higher endometrial cancer.
\end{abstract}

Key words: laparoscopic surgery, endometrial cancer, lymphadenectomy

\section{緒言}

近年、我が国の子宮体癌の罹患者数は急速に増 加している。一方、手術の低侵襲化は社会のニー ズであり、各科で内視鏡下の手術が増加傾向にあ る。2014年に子宮体癌の一部に対する腹腔鏡下手
術が保険収載され、今後腹腔鏡下に子宮体癌の手 術を行う機会は増加すると思われる。しかしなが ら、本邦での子宮体癌に対する腹腔鏡下手術の成 績に関する報告は、諸外国に比して少ない。

当院では2012年の開院以来、子宮体癌に対する 腹腔鏡下手術を倫理委員会の承認のもとで行って 
きた。そこで、これまでの症例を後方視的に解析 し、当院に打ける腹腔鏡下子宮体癌手術の feasibilityを評価した。

\section{対象と方法}

2012年 8 月より 2016年 6 月の間に、当院におい て子宮体癌の診断で腹腔鏡下手術を行った 91 症例 を対象とした。診療録をもとに、手術内容・出血 量 - 手術時間 - 術後在院日数・摘出した骨盤掞よ び傍大動脈リンパ節の個数・合併症・予後を後方 視的に解析した。合併症は、NCI (National Cancer Institute) のCTCAE (Common Terminology Criteria for Adverse Events) ver.4.0における grade3以上の事象の発生頻度を評価した。予後 に関しては、2016年10月時点での再発および生存 を評価し、再発パターンを検討した。

\section{当院の治療基準}

全例手術前に子宮内膜組織診を行い、子宮体癌 であることを確認する。さらに造影MRI、PETCTを併用してFIGO進行期を推定する。組織型が 類内膜腺癌G1もしくはG2であり、FIGOIA期が 疑われ、さらに筋層浸潤が否定的な症例には腹腔 鏡下子宮全摘術 (Total Laparoscopic Hysterectomy, TLH） および両側付属器摘出術（Bilateral Salpingo-Oophorectomy, BSO）を行う。1/2未満 の筋層浸潤が疑われる症例は、当初はTLHと BSOのみを行っていたが、2014年 5 月以降は TLHとBSOに加えて骨盤リンパ節郭清 (Pelvic Lymphadenectomy, PLN）を行っている。その 他の症例（術前の組織型が類内膜腺癌 $\mathrm{G} 1 \cdot \mathrm{G} 2$ で はない、もしくはFIGOIB期以上が推定される症
例）にはTLHとBSOに加えてPLNと傍大動脈リ ンパ節郭清 (Para-Aortic Lymphadenectomy, PAN）を行い、明細胞腺癌・漿液性腺癌症例に はさらに大網切除を追加している。腹腔内の播種 が疑われる症例、開腹術の希望がある症例に対し ては、同様の操作を開腹術にて行っている。腹腔 鏡下にPANを行う場合、文書による同意を得た うえで自費診療として行っている。

TLHとBSOを行う場合、もしくはPLNを追加 する場合、ダイアモンド型の 4 ポートを利用し、 PANを追加する場合はさらに左下腹部に 3 ポー 卜を追加して行っている（図 1 ）。術式の基準と 手術の手順を図 2 に示す。PANは通常後腹膜ア プローチで行っているが、後腹膜腔の気腹の維持、 後腹膜リンパ節への鉗子の到達が困難な場合は腹 腔内よりアプローチしている。PANの上縁は 326b1領域とし、PLNの上縁は総腸骨リンパ節と している。子宮マニピュレーター ${ }^{\circledR}$ (アトムメデ イカル、東京）を挿入することは、特に禁止して いない。ただし卵管を凝固した後、腹腔鏡観察下 に子宮を穿孔しないよう留意しながら挿入してい る。子宮は、筋層浸潤の深さや頸管浸潤の有無に

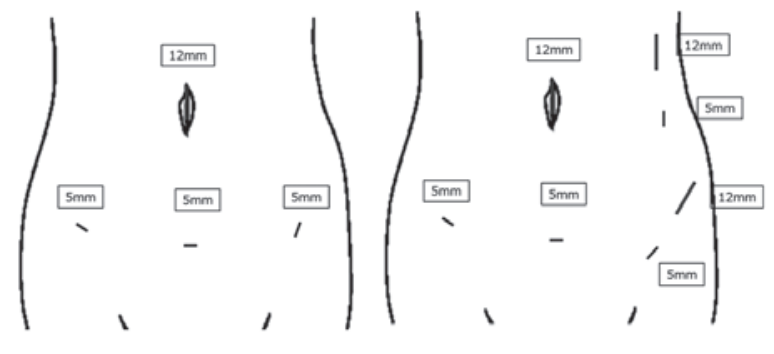

TLH /BSO /PLN /PAN

図 1 ポート配置

\begin{tabular}{|c|c|c|c|c|c|}
\hline 術前診断 & & 手術 & ポート数 & & 手順 \\
\hline \multirow[t]{2}{*}{ - G1 or G2かつIA期疑い } & $\begin{array}{c}\text { 筋屬浸潤 } \\
\text { なし }\end{array}$ & TLH/ BSO & 4 & & $\begin{array}{l}\text { 1. 腹肸内観察 } \\
\text { 2. } \mathrm{TLH} / \mathrm{BSO}\end{array}$ \\
\hline & $\begin{array}{c}\text { 筋㞗浸潤 } \\
\text { あり }\end{array}$ & TLH/ BSO/ PLN & 4 & & $\begin{array}{l}\text { 1. 腹腔内観察 } \\
\text { 2. TLH/ } \\
\text { 3. PLN }\end{array}$ \\
\hline \multirow[t]{2}{*}{ · 上記以外 } & & $\begin{array}{c}\text { TLH/ BSO/ PLN/ } \\
\text { PAN/ OMT** }\end{array}$ & 7 & $\begin{array}{l}\text { 後腹膜 } \\
\text { アナロロ-チ }\end{array}$ & $\begin{array}{l}\text { 1. 腹腔内観察 } \\
\text { 2. PAN } \\
\text { 3. TLH / BSO } \\
\text { 4. PLN } \\
\text { 5. OMT }\end{array}$ \\
\hline & & & & $\begin{array}{l}\text { 経腹膜 } \\
\text { アプローチ }\end{array}$ & $\begin{array}{l}\text { 1. 腹腔内観察 } \\
\text { 2. TLH/ B BSO } \\
\text { 3. PAN } \\
\text { 4. PLN } \\
\text { 5. OMT }\end{array}$ \\
\hline
\end{tabular}


関わらず、開腹による単純子宮全摘術と同様に、 子宮頸部を残さないよう腟壁を多少なりとも切除 する筋膜外術式にて摘出している。摘出した子宮 と両側付属器は回収バッグに入れて腟より体外に 搬出するが、困難な場合は下腹部に小切開を加え て搬出する。リンパ節は回収バックを用いて体外 に搬出している。

術後、子宮体がん治療ガイドライン ${ }^{1)}$ に従って 再発のリスクを評価する。再発高リスク症例に対 しては補助化学療法としてTC療法（パクリタキ セル+カルボプラチン）を6コース施行する。中 リスク症例に対しては補助化学療法（TC療法6コ ース）を行うか経過観察とするか患者と相談して 決定する。低リスク症例は経過観察を行う。

\section{結 果}

患者背景を表 1 に示す。年齢中央値は56歳、 BMI中央值は23.8であった FIGOステージは 69.2\%がIA期であり、組織型は78.0\%が類内膜腺 癌G1であった。施行術式の内訳と手術時間、出 血量、術後在院日数、摘出リンパ節個数を表 2 に 示す。PLNを行った症例は34例 (37.4\%)、PAN を行った症例は28例（30.8\%）であり、摘出した リンパ節個数の中央值はそれぞれ31.5個、24.5個 であった。子宮マニピュレーターは15例 (16.5\%) に使用し、うち 1 例 $(6.7 \%)$ に再発を認めた。子 宮マニピュレーターを抻入することで再発率は変 わらなかった。PANは25例（89.3\%）が後腹膜ア プローチで行っていた。91例中 3 例 (3.3\%) が、 下腹部小切開により子宮、付属器を体外に搬出し ていた。同期間に開腹による子宮体癌手術を 4 例 行っており、腹腔鏡下手術が全体の $95.8 \%$ 占め ていた。

手術合併症のまとめを表 3 に示す。下大静脈、 下腸間膜動脈、閉鎖神経などを損傷し、計 6 症例 （6.6\%）にgrade3以上の術中合併症を認めたが、
いずれも鏡視下に修復可能であった。術後合併症 としてイレウスを 2 例、感染性リンパ異胞を 2 例、 腟断端離開を 1 例、腟断端出血を 1 例に認めた。 イレウスはいずれも後腹膜アプローチでPANを 行った症例に発症しており、これはポート設置部 位もしくはポートに利用した腹膜欠損部位への小 腸嵌頓に伴うものであった。イレウス 2 例と腟断 端離開の症例で再手術を必要とした。開腹術への 移行、同種血輸血を行った症例はなかった。

手術後の経過観察期間の中央值は 23 月で、 5 例 (5.5\%) に再発を認めたが、現病による死亡症 例は認めなかった。再発した 5 症例の詳細を表 4 に示す。初再発部位は傍大動脈リンパ節、腹膜播 種、肺など多岐に渡っており、一定の傾向は認め なかった。症例 1 は左側傍大動脈リンパ節の $326 \mathrm{a} 2$ 領域と鎖骨上窩リンパ節に同時に再発し、 症例 3 は左側中心の $326 \mathrm{~b} 2$ 領域周囲に数珠状に再

表 1 患者背景

$\begin{array}{lll}\text { Age (median) } & & 56(34-80) \\ \text { BMI (median) } & & 23.8(17.0-38.4) \\ \text { Parity } & 0 & 34(37.4 \%) \\ \text { FIGO stage } & \text { IA } & 57(62.6 \%) \\ & \text { IB } & 63(69.2 \%) \\ & \text { II } & 16(17.6 \%) \\ & \text { III } & 2(2.2 \%) \\ & \text { II B } & 3(3.3 \%) \\ & \text { II C1 } & 1(1.1 \%) \\ & \text { II } 2 & 1(1.1 \%) \\ \text { Histology } & \text { G1 } & 2(2.2 \%) \\ & \text { G2 } & 71(78.0 \%) \\ & \text { G3 } & 9(9.9 \%) \\ & \text { Serous } & 7(7.7 \%) \\ \text { Clear } & 3(3.3 \%) \\ & & 1(1.1 \%)\end{array}$

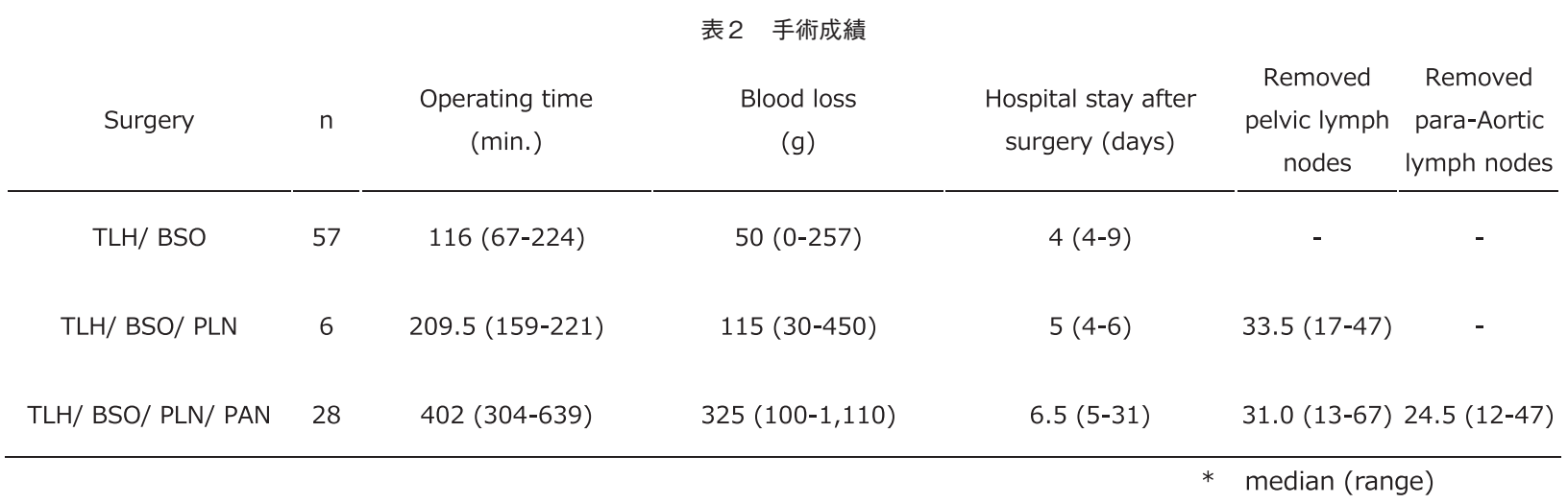


表 3 術中・術後合併症（NCI-CTCAE ver.4.0でgrade3以上）

n $\%$

$\begin{array}{ccc}\text { Intraoperative complications } & & \\ \text { Any } & 6 & 6.6 \\ \text { Bowel } & 0 & 0 \\ \text { Vein } & 4 & 4.4 \\ \text { Artery } & 1 & 1.1 \\ \text { Bladder } & 0 & 0 \\ \text { Ureter } & 0 & 0 \\ \text { Other } & 2 & 2.2\end{array}$

Postoperative adverse events

$\begin{array}{lll}\text { Any } & 6 & 6.6 \\ \text { Ileus } & 2 & 2.2 \\ \text { Abscess } & 2 & 2.2 \\ \text { Stump dehiscence } & 1 & 1.1 \\ \text { Stump bleeding } & 1 & 1.1\end{array}$

発し、右側にも再発した。症例 3 は術後に後腹膜 膿瘍を発症し、ドレナージや抗生剂投与などの治 療を長期間必要としたため、当方からの強い锥め にも関わらず、術後化学療法を行うことに同意さ れなかった。IIIB期の症例（症例 4）は子宮傍組 織まで悪性腫瘍の直接浸潤を認めたが、切除断端 は除性であった。再発した 5 例中 2 例は、化学療 法により寛解を得ている。

\section{考察}

子宮体癌に対する腹腔鏡下手術と開腹手術を比 較したランダム化比較試験において、腹腔鏡下手 術の方が手術時間は長くなるものの、出血量 - 入 院期間は少なかったと報告されている2-4)。また、 術中合併症の頻度は同程度で、術後合併症の頻度
は腹腔鏡下手術が有意に少なかったとする報告が 多( ${ }^{2,3)}$ 。

今回の検討で、NCI-CTCAE ver4.0における grade 3 以上の術中合併症は6.6\%、術後合併症は $6.6 \%$ に認め、開腹術への移行や同種間輸血を必要 とした症例は認めなかった。腹垫鏡下手術と開腹 手術を比較した上述の論文 ${ }^{2-4)}$ では、術中合併症 が $2.7-10 \%$ 、術後合併症が11.6-11.9\%程度で、 腹腔鏡下手術から開腹手術への移行率は3.7 $25.8 \%$ 、腹腔鏡下手術での同種間輸血の頻度は 3.2 $-9 \%$ と報告している。これらの論文との比較は 患者背景が異なり必ずしも適切ではないが、当院 での手術に打ける合併症・開腹移行・同種血輸血 は低頻度と考察できる。しかしながら術後合併症 として腹腔鏡特有ともいえる、腟断端離開やポー ト設置に伴うイレウスなどの合併症を認めてい る。合併症発症後は、ポート設置部位に小腸が嵌 頓しないよう、閉腹時に腹腔鏡下に腹膜欠損部を 縫合している。また、今回の腟断端離開は一般的 に言われている性交涉や感染などが要因ではなく 発症の原因は不明である。しかしながら腟断端に 対する焼灼を最小限とし、血流不全に起因する胵 断端離開を減らすよう努めている。

子宮マニピュレーターについては、挿入により 腹腔細胞診の陽性率や脈管侵襲様の所見 （Vascular Pseudoinvasion）が増加するという報 告がある ${ }^{5)}$ 。しかし腹腔細胞診の予後に与える影 響は明らかではない。病理医は子宮マニピュレー ター挿入で生じるアーチファクトとしての Vascular Pseudoinvasion を認識しておく必要が あり ${ }^{6)}$ 、臨床医は子宮マニピュレーターの使用を 病理医に伝え、過剩医療を防ぐ必要があると報告 されている7。また、子宮マニピュレーターの挿

表 4 再発症例

\begin{tabular}{|c|c|c|c|c|c|c|}
\hline & Age & Stage & Histology & Initial therapy & Recurrent pattern & Status \\
\hline 1 & 79 & III C2 & G3 & TLH/ BSO/ PLN/ PAN + TC6 & 11m. Para-Ao LN/Virchow & NED \\
\hline 2 & 69 & IA & Clear & TLH/ BSO/ PLN/ PAN/OMT + TC6 & 12m. Abd. dissemination & NED \\
\hline 3 & 73 & III 2 & Serous & TLH/ BSO/ PLN/ PAN & 5m. Para-Ao LN & AWD \\
\hline 4 & 57 & III $B$ & G3 & TLH/ BSO/ PLN/ PAN + TC6 & $15 \mathrm{~m}$. lung & AWD \\
\hline 5 & 68 & IIIA & G3 & TLH/ BSO/ PLN/ PAN/OMT + TC6 & 8m. Inguinal LN & AWD \\
\hline
\end{tabular}

* TC: Paclitaxel-carboplatin, NED: no evidence of disease, AWD: alive with disease 
入の有無を比較したRCT (randomized clinical trial）で、腹腔内細胞診陽性率・脈管侵襲の頻度 は変わらなかったと報告されている8)。これまで に子宮マニピュレーターの挿入が予後を悪化させ たという報告はなく、最近のイタリアの多施設の 検討では、子宮マニピュレーターの挿入は再発率 に寄与せず、Disease specific survival・ Overall survival・再発部位に影響を与えなかった 院では、子宮を穿孔しなければ使用に問題ないと 考え、特に制限していない。

複数のランダム化比較試験において、子宮体癌 症例に所属リンパ節摘出を追加することの治療的 な意義は見出せなかった ${ }^{10,11)}$ 。しかしこれらの患 者背景や検討方法には様々な意見があり、また、 リンパ節摘出が重要な進行期決定の手技であるこ とに議論の余地はない。腹腔鏡下手術でも開腹手 術と同等数のリンパ節を安全に摘出できることが 示されており ${ }^{12,13)}$ 、手術の低侵襲化が求められる 昨今、サージカルステージングとしての腹腔鏡下 手術は増加していくと推測される。当院でリンパ 節郭清を行った症例において、摘出した骨盤リン パ節個数の中央值は31.5個、傍大動脈リンパ節個 数の中央值は24.5個であった。これは他の報告と 比較して遜色ない数值であり ${ }^{4,12,13)}$ 、当院でも十分 にリンパ節を摘出できていると思われた。

予後に関しては、本検討は症例数が少なく経過 観察期間が短いため評価困難である。LAP2ス夕 ディは2012年に、開腹による子宮体癌手術と腹腔 鏡による子宮体癌手術で推定 5 年生存率が同等で あったと追加報告しており ${ }^{14)}$ 、腹腔鏡で行うこと で予後が悪化したという報告はない。現在はIA 期症例のみ保険診療として認められているが、そ の他の早期子宮体癌症例に腹腔鏡手術の適応を拡 大することは、本邦の子宮体癌患者にとって大き な利益をもたらすと思われる。

本邦でも腹腔鏡下の子宮体癌手術は増加傾向に あると推測されるが、成績・予後に関する報告は 少なく、後方視的検討を散見するのみである ${ }^{15.16) 。}$ 手術の方法や工夫、合併症などを知識として共有 し、症例を集積することが、本邦での安全な腹腔 鏡下子宮体癌手術の普及につながると思われる。

\section{結論}

当院に打ける腹腔鏡下子宮体癌手術の feasibilityを評価した。子宮体癌に対する腹腔鏡 下手術は、IA期以外の症例に対しても安全に施 行できる可能性がある。本邦からのさらなる報告
が期待される。

*本論文の要旨は第56回日本産科婦人科内視鏡学 会に抒いて発表した。

\section{文献}

1) 日本婦人科腫瘍学会. 子宮体がん治療ガイドライン 2013.

2) Mourits MJ, Bijen CB, Arts HJ, et al. Safety of laparoscopy versus laparotomy in early-stage endometrial cancer: a randomised trial. Lancet Oncol. Aug $2010 ; 11$ (8) : 763-771.

3) Janda M, Gebski V, Brand A, et al. Quality of life after total laparoscopic hysterectomy versus total abdominal hysterectomy for stage I endometrial cancer (LACE) : a randomised trial. Lancet Oncol. Aug $2010 ; 11$ (8) : 772-780.

4) Walker JL, Piedmonte MR, Spirtos NM, et al. Laparoscopy Compared With Laparotomy for Comprehensive Surgical Staging of Uterine Cancer: Gynecologic Oncology Group Study LAP2. Journal of Clinical Oncology. 2009 ; 27 (32) : 5331-5336.

5 ) Marcos-Sanmartin J, Lopez Fernandez JA, SanchezPaya J, et al. Does the Type of Surgical Approach and the Use of Uterine Manipulators Influence the Disease-Free Survival and Recurrence Rates in Early-Stage Endometrial Cancer? Int J Gynecol Cancer. Nov 2016 ; 26 (9) : 1722-1726.

6 ) Logani S, Herdman AV, Little JV, Moller KA. Vascular "pseudo invasion" in laparoscopic hysterectomy specimens: a diagnostic pitfall. Am J Surg Pathol. Apr $2008 ; 32$ (4) : 560-565.

7 ) Kitahara S, Walsh C, Frumovitz M, Malpica A, Silva EG. Vascular pseudoinvasion in laparoscopic hysterectomy specimens for endometrial carcinoma: a grossing artifact? Am J Surg Pathol. Feb 2009 ; 33 (2) : 298-303.

8 ) Lee M, Kim YT, Kim SW, Kim S, Kim JH, Nam EJ. Effects of uterine manipulation on surgical outcomes in laparoscopic management of endometrial cancer: a prospective randomized clinical trial. Int J Gynecol Cancer. Feb 2013 ; 23 (2) : 372-379.

9) Uccella S, Bonzini M, Malzoni M, et al. The Effect of a Uterine Manipulator on the Recurrence and Mortality of Endometrial Cancer: A Multi-Centric Study by the Italian Society of Gynecological Endoscopy. Am J Obstet Gynecol. Jan 292017.

10) Tozzi R, Malur S, Koehler C, Schneider A. Laparoscopy versus laparotomy in endometrial cancer : first analysis of survival of a randomized prospective study. J Minim Invasive Gynecol. MarApr $2005 ; 12$ (2) : 130-136.

11) Kitchener H, Swart AM, Qian Q, Amos C, Parmar 
MK. Efficacy of systematic pelvic lymphadenectomy in endometrial cancer (MRC ASTEC trial) : a randomised study. Lancet. Jan 102009 ; 373 (9658) : 125-136.

12) Benito V, Romeu S, Esparza M, et al. Safety and Feasibility Analysis of Laparoscopic Lymphadenectomy in Pelvic Gynecologic Malignancies: A Prospective Study. Int J Gynecol Cancer. Nov 2015 ; 25 (9) : 1704-1710.

13) Kyrgiou M, Swart AM, Qian W, Warwick J. A Comparison of Outcomes Following Laparoscopic and Open Hysterectomy With or Without Lymphadenectomy for Presumed Early-Stage Endometrial Cancer: Results From the Medical Research Council ASTEC Trial. Int J Gynecol Cancer. Oct $2015 ; 25$ (8) : 1424-1436.

14) Walker JL, Piedmonte MR, Spirtos NM, et al. Recurrence and Survival After Random Assignment to Laparoscopy Versus Laparotomy for Comprehensive Surgical Staging of Uterine Cancer: Gynecologic Oncology Group LAP2 Study. Journal of Clinical Oncology. $2012 ; 30$ (7) : 695-700.

15）野崎綾子, 小田切哲二, 勘野真紀, 光部兼六郎, 古田祐, 前田悟郎, 細川严美, 山口正博, 定免裕子, 山田恭子, 福 本俊, 吉井一樹, 朝野拓史, 野村英司, 工藤正尊. 早期子 宮体癌に対する腹腔鏡下手術の周術期経過と長期予 後について. 日本産科婦人科内視鏡学会雑誌. 2015 ; 31 (1) : 120-125.

16）近藤英司, 竹島信宏. 当院における腹腔鏡下子宮体癌 根治術の検討. 産婦人科の実際. 2016 ; 65 (3) : 341-346.

投稿日：2017年 1 月16日

採択日：2017年 5 月 24 日 